\title{
Comparison of percutaneous MitraClip versus mitral valve surgery for severe mitral regurgitation: a meta-analysis
}

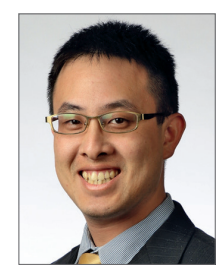

Tom Kai Ming Wang ${ }^{1,2, *}$ MBCHB, FRACP, MD(res); Andrew Chatfield ${ }^{1}$, MBCHB; Michael Tzu Min Wang ${ }^{1}$, MBCHB; Peter Ruygrok ${ }^{1}$, MBCHB, FRACP, MD(res)

1. Green Lane Cardiovascular Service, Auckland City Hospital, Auckland, New Zealand; 2. Department of Cardiovascular Medicine, Cleveland Clinic, Cleveland, OH, USA

\section{KEYWORDS \\ - mitral regurgitation \\ - mitral valve \\ disease \\ - mitral valve repair}

\begin{abstract}
Aims: Mitral valve surgery (MVS) is the gold-standard treatment for severe symptomatic mitral regurgitation. Percutaneous mitral valve interventions such as the MitraClip procedure offer another dimension to its management particularly in high-risk patients. We meta-analysed the outcomes of MitraClip and MVS.

Methods and results: PubMed, MEDLINE, Embase, Cochrane and Scopus from 1980/01-2019/06 were searched for eligible studies. Data were extracted and pooled using random-effects models. After screening 959 studies and reviewing 21 full-text articles, nine studies totalling 640 MitraClip and 531 MVS (91\% valve repair) procedures were included in the meta-analysis. MitraClip patients were older, with a higher prevalence of previous cardiac surgery, coronary disease and a higher EuroSCORE (all $p<0.05$ ) than MVS patients. Pooled operative mortality was similar for MitraClip, $3 \%$, versus MVS, $5 \%$, odds ratio (OR): 0.58 , $95 \%$, CI: $0.28-1.19$, as well as at 1 year mortality, OR: 1.09 , CI: $0.71-1.68$ and 3-year mortality, OR: 1.08, CI: 0.72-0.163. MitraClip patients had higher rates of early and late significant mitral regurgitation (MR) and more cardiovascular readmissions, while MVS had higher rates of in-hospital bleeding and pacemaker implantation (all $\mathrm{p}<0.05$ ).
\end{abstract}

Conclusions: MitraClip patients had a higher baseline risk than MVS, but there were no significant differences in short- and long-term mortality. MitraClip patients had higher rates of cardiovascular admissions and significant MR post-operatively, while MVS patients had more procedural complications.

*Corresponding author: Green Lane Cardiovascular Service, Auckland City Hospital, 2 Grafton Road, Grafton, Auckland 1023, 


\section{Abbreviations}

95\% CI $95 \%$ confidence interval

MR mitral regurgitation

MVS mitral valve surgery

OR odds ratios

WMD weighted mean differences

\section{Introduction}

Mitral regurgitation (MR) is a common form of valvular heart disease affecting $2-12 \%$ of the general population, and is the second most common valvular indication for cardiac surgery ${ }^{1-4}$. The aetiology of MR is conventionally divided into primary, as a disease affecting valve leaflets, or secondary, with pathology of the mitral valve apparatus and/or left ventricle excluding valve leaflets $^{1,2}$. This classification is important in the prognosis, which is worse for secondary MR, and in the determination of management strategy ${ }^{6,7}$. Mitral valve surgery (MVS) is the established gold standard method for treating severe primary MR with symptoms, impaired left ventricular ejection fraction, dilated left ventricular end-systolic diameter, new onset atrial fibrillation or severe pulmonary hypertension, and surgical repair is preferable to replacement where feasible ${ }^{1,2}$. The efficacy of MVS in treating primary MR has not translated to the treatment of secondary MR, where management remains controversial, creating an unmet need in these and other high-risk candidates with severe $\mathrm{MR}^{8,9}$.

Minimally invasive procedures for valvular heart disease have blossomed over the last decade, and for MR, the percutaneous MitraClip $^{\mathrm{TM}}$ (Abbott Vascular, Santa Clara, CA, USA) procedure was the first readily available technology ${ }^{10}$. EVEREST-II was the first randomised trial comparing the MitraClip procedure to MVS for primary $\mathrm{MR}^{11}$. Two further trials explored the MitraClip procedure compared to medical therapy for secondary MR with conflicting results ${ }^{12,13}$. Nevertheless there remains limited randomised evidence for the MitraClip procedure and its exact role and indications remain controversial. This meta-analysis compared the efficacy and safety outcomes of the MitraClip procedure with MVS in patients with severe MR.

\section{Methods \\ LITERATURE SEARCH}

The meta-analysis was conducted in accordance to the PRISMA guidelines. Relevant studies and abstracts, from January 1, 1980 to June 30, 2019, were identified through searching five electronic databases including Medline, Embase, PubMed, Cochrane Central Register for Controlled Trials (CENTRAL), and Scopus. The search terms used were "MitraClip", "percutaneous", "transcatheter", "catheter-based", or "endovascular"; AND "mitral regurgitation". The reference lists of retrieved articles were then screened for potentially relevant studies. Two reviewers (TW and MW) independently conducted the search and evaluated studies for inclusion. Differences were resolved by discussion and consensus.

\section{INCLUSION AND EXCLUSION CRITERIA}

Original studies comparing the MitraClip procedure and mitral valve surgery outcomes in more than twenty adult human subjects (over 18 years of age) with significant mitral regurgitation were eligible for inclusion. Mortality outcomes for both the MitraClip procedure and MVS had to be reported. Both randomised trials and observational studies were included, and reviews were excluded. When multiple publications reported results from the same trial or cohort, data were extracted and pooled as one study.

\section{DATA EXTRACTION}

Three reviewers (TW, AC and MW) independently extracted data, using standardised forms. Differences were resolved by discussion and consensus. Data were extracted on study design, patient and intervention characteristics, and both short- and long-term mortality and morbidity outcome measures.

\section{STATISTICAL ANALYSIS}

Statistical analyses were performed using Review Manager Version 5.3 (Cochrane Collaboration, Oxford, UK). Variables reported by two or more studies were pooled. Meta-analyses were conducted using odds ratios (OR) or weighted mean differences (WMD) with $95 \%$ confidence intervals $(95 \% \mathrm{CI})$, some presented as forest plots. Random effects modelling was utilised to account for potential variation in methodology and participant characteristics between studies. Heterogeneity of studies and publication bias were assessed using the $\mathrm{I}^{2}$ test and funnel plots for each outcome pooled, and no significant heterogeneity or evidence of publication bias were found for any outcomes. All tests were two-tailed and $\mathrm{p}<0.05$ was considered significant.

\section{Results}

There were 959 articles identified from the literature search. Following abstract review and exclusion of 938 unrelated or duplicate articles, the 21 full-text articles were evaluated. Six of these studies did not report both treatment modalities of interest, and six were duplicate trials, leaving nine studies meeting the inclusion criteria selected for subsequent analysis ${ }^{11,14-22}$. The study design of included studies is summarised in Table 1. There was one randomised trial and eight retrospective observational cohort studies, totalling 1,171 patients (640 MitraClip procedures and $531 \mathrm{MVS}$ ), followed-up for 6-60 months.

Patient characteristics for both treatment arms of these studies are shown in Table 2. In the MVS arm, 485 (91\%) were mitral valve repairs. MitraClip patients were older, had higher proportion of previous cardiac surgery, coronary artery disease, and logistic EuroSCORE 1, while the proportion of males, patients with New York Heart Association (NYHA) classification III-IV, functional MR and left ventricular ejection fraction (LVEF) ranges were similar between the two arms.

Figure 1 illustrates the forest plots for pooled mortality outcomes. There were no statistically significant differences between the MitraClip procedure and MVS for operative mortality, 3\% 
Table 1. Design of included studies.

\begin{tabular}{|c|c|c|c|c|c|c|}
\hline Author/Year & Country & Time of procedures & Centres & Study design & $\begin{array}{c}\text { Total patients } \\
\text { (MitraClip, MVS) }\end{array}$ & $\begin{array}{l}\text { Follow-up } \\
\text { (months) }\end{array}$ \\
\hline $\begin{array}{l}\text { Feldman } \\
2011^{11}+2015^{14}\end{array}$ & United States/Canada & Sep 2005-Nov 2008 & 37 & Randomised trial & $279(184,95)$ & 60 \\
\hline Taramasso $2012^{15}$ & Italy & Mar 2000-Apr 2011 & 1 & Retrospective cohort & $143(52,91)$ & $8.5,18$ \\
\hline Conradi $2013^{16}$ & Germany & Mar 2002-June 2010 & 1 & Retrospective cohort & $171(95,76)$ & 6 \\
\hline Paranskaya $2013^{17}$ & Germany & Apr 2010-Dec 2011 & 1 & Retrospective cohort & $50(24,26)$ & 12 \\
\hline Swaans $2014^{18}$ & the Netherlands & Jan 2009-Apr 2013 & 1 & Retrospective cohort & $192(139,53)$ & 20,32 \\
\hline Buzzatti $2014^{19}$ & Switzerland & Sep 2008-Apr 2014 & 1 & Retrospective cohort & $60(25,35)$ & 22,30 \\
\hline De Bonis $2015^{20}$ & Italy & 1999-2006 and 2008-2011 & 1 & Retrospective cohort & $120(55,65)$ & 48 \\
\hline Ondrus $2016^{21}$ & Belgium & 1997 onwards & 1 & Retrospective cohort & $72(24,48)$ & 34,30 \\
\hline Alozie $2017^{22}$ & Germany & Oct 2008-Oct 2014 & 1 & Retrospective cohort & $84(42,42)$ & 9,25 \\
\hline Total (9 studies) & & & & & $1,171(640,531)$ & \\
\hline
\end{tabular}

\begin{tabular}{|c|c|c|c|c|c|c|c|c|c|c|}
\hline $\begin{array}{l}\text { A } \\
\text { Study or Subgroup }\end{array}$ & \multicolumn{2}{|c|}{ MitraClip } & \multicolumn{2}{|c|}{ Surgery } & Weight & $\begin{array}{c}\text { Odds Ratio } \\
\text { M-H, Random, } 95 \% \mathrm{Cl}\end{array}$ & \multicolumn{3}{|c|}{$\begin{array}{c}\text { Odds Ratio } \\
\text { M-H, Random, } 95 \% \mathrm{Cl}\end{array}$} & \\
\hline Alozie 2017 & 2 & 42 & 3 & 42 & $15.4 \%$ & $0.65[0.10,4.10]$ & & & & \\
\hline Buzzatti 2015 & 1 & 25 & 0 & 35 & $5.0 \%$ & $4.35[0.17,111.19]$ & & & & \\
\hline Conradi 2013 & 4 & 95 & 2 & 76 & $17.6 \%$ & $1.63[0.29,9.13]$ & & & & \\
\hline De Bonis 2015 & 0 & 55 & 3 & 65 & $5.9 \%$ & $0.16[0.01,3.18]$ & & & & \\
\hline Feldman 2011 & 6 & 184 & 6 & 95 & $38.9 \%$ & $0.50[0.16,1.59]$ & & & - & \\
\hline Ondrus 2016 & 1 & 24 & 6 & 48 & $11.0 \%$ & $0.30[0.03,2.68]$ & & & & \\
\hline Paranskaya 2013 & 0 & 24 & 0 & 26 & & Not estimable & & & & \\
\hline Taramasso 2012 & 0 & 52 & 6 & 91 & $6.2 \%$ & $0.13[0.01,2.27]$ & & & & \\
\hline Total $(95 \% \mathrm{Cl})$ & & 501 & & 478 & $100.0 \%$ & $0.58[0.28,1.19]$ & & & & \\
\hline Total events & 14 & & 26 & & & & & & & \\
\hline \multicolumn{7}{|c|}{$\begin{array}{l}\text { Heterogeneity: } \text { Tau }^{2}=0.00 ; \mathrm{Chi}^{2}=5.11, \mathrm{df}=6(\mathrm{P}=0.53) ; I^{2}=0 \% \\
\text { Test for overall effect: } Z=1.48(\mathrm{P}=0.14)\end{array}$} & 0.002 & $2 \underset{11}{0.1}$ & Favours Surgery & 500 \\
\hline \multicolumn{11}{|c|}{ 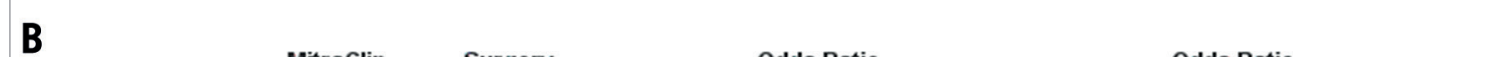 } \\
\hline Study or Subgroup & Events & Total & Events & Total & Weight & M-H, Random, $95 \% \mathrm{Cl}$ & \multicolumn{4}{|c|}{$\begin{array}{c}\text { Odds Ratio } \\
\text { M-H, Random, } 95 \% \mathrm{Cl}\end{array}$} \\
\hline Alozie 2017 & 4 & 42 & 9 & 42 & $11.7 \%$ & $0.39[0.11,1.37]$ & & & F & \\
\hline Buzzatti 2015 & 9 & 25 & 7 & 35 & $13.8 \%$ & $2.25[0.70,7.20]$ & & & & \\
\hline Feldman 2011 & 11 & 184 & 6 & 95 & $17.8 \%$ & $0.94[0.34,2.63]$ & & & & \\
\hline Ondrus 2016 & 7 & 24 & 10 & 48 & $14.9 \%$ & $1.56[0.51,4.81]$ & & & & \\
\hline Paranskaya 2013 & 2 & 24 & 0 & 26 & $2.0 \%$ & $5.89[0.27,129.15]$ & & & & \\
\hline Swaans 2014 & 20 & 139 & 8 & 53 & $23.7 \%$ & $0.95[0.39,2.30]$ & & & & \\
\hline Taramasso 2012 & 6 & 52 & 10 & 91 & $16.2 \%$ & $1.06[0.36,3.10]$ & & & & \\
\hline Total $(95 \% \mathrm{Cl})$ & & 490 & & 390 & $100.0 \%$ & $1.09[0.71,1.68]$ & & & & \\
\hline Total events & 59 & & 50 & & & & & & & \\
\hline \multicolumn{7}{|c|}{$\begin{array}{l}\text { Heterogeneity: } \mathrm{Tau}^{2}=0.00 ; \mathrm{Chi}^{2}=5.79, \mathrm{df}=6(\mathrm{P}=0.45) ; \mathrm{I}^{2}=0 \% \\
\text { Test for overall effect: } Z=0.40(\mathrm{P}=0.69)\end{array}$} & 0.01 & $\begin{array}{cc}0.1 & 1 \\
\text { Favours MitraClip } & 1\end{array}$ & $\begin{array}{c}10 \\
\text { Favours Surgery }\end{array}$ & 100 \\
\hline C & \multicolumn{2}{|c|}{ MitraClip } & \multicolumn{2}{|c|}{ Surgery } & & Odds Ratio & \multirow{2}{*}{\multicolumn{4}{|c|}{$\begin{array}{c}\text { Odds Ratio } \\
\text { M-H, Random, } 95 \% \mathrm{Cl}\end{array}$}} \\
\hline Study or Subgroup & Events & Total & Events & Total & Weight & M-H, Random, $95 \% \mathrm{Cl}$ & & & & \\
\hline Buzzatti 2015 & 19 & 25 & 21 & 35 & $9.8 \%$ & $2.11[0.68,6.60]$ & & & & \\
\hline De Bonis 2015 & 13 & 55 & 20 & 65 & $19.2 \%$ & $0.70[0.31,1.57]$ & & & & \\
\hline Feldman 2011 & 29 & 184 & 17 & 95 & $29.5 \%$ & $0.86[0.44,1.66]$ & & & & \\
\hline Ondrus 2016 & 13 & 24 & 29 & 48 & $13.0 \%$ & $0.77[0.29,2.08]$ & & & & \\
\hline Swaans 2014 & 52 & 139 & 17 & 53 & $28.3 \%$ & $1.27[0.65,2.48]$ & & & $\rightarrow-$ & \\
\hline Total $(95 \% \mathrm{Cl})$ & & 427 & & 296 & $100.0 \%$ & $0.99[0.69,1.42]$ & & & & \\
\hline Total events & 126 & & 104 & & & & & & & \\
\hline $\begin{array}{l}\text { Heterogeneity: Tau }{ }^{2}= \\
\text { Test for overall effect }\end{array}$ & $\begin{array}{l}=0.00 ; \mathrm{Ch} \\
: Z=0.04\end{array}$ & $\begin{aligned} & i^{2}=3.3 \\
&(P=0.9\end{aligned}$ & $\begin{array}{l}4, d f=4( \\
97)\end{array}$ & $P=0.5$ & $00 ; I^{2}=0 \%$ & & 0.1 & \begin{tabular}{cc|}
0.2 & 0.5 \\
Favours & MitraClip
\end{tabular} & 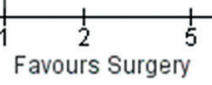 & 10 \\
\hline
\end{tabular}

Figure 1. Forest plot of pooled odds ratios comparing MitraClip and MVS for mortality A) operative, B) 1 year and C) 3 years. M-H: Mantel-Haenszel method 
Table 2. Patient characteristics of included studies.

\begin{tabular}{|c|c|c|c|c|c|c|c|c|}
\hline Author/Year & $\begin{array}{c}\text { Age } \\
\text { (years) }\end{array}$ & $\begin{array}{l}\text { Male } \\
(\%)\end{array}$ & $\begin{array}{c}\text { Previous cardiac } \\
\text { surgery (\%) }\end{array}$ & $\begin{array}{c}\text { Coronary artery } \\
\text { disease (\%) }\end{array}$ & $\begin{array}{c}\text { Functional } \\
\text { MR (\%) }\end{array}$ & $\begin{array}{c}\text { NYHA 3-4 } \\
(\%)\end{array}$ & $\begin{array}{l}\text { LVEF } \\
(\%)\end{array}$ & $\begin{array}{c}\text { EuroSCORE I } \\
(\%)\end{array}$ \\
\hline Feldman $2011^{11}+2015^{14}$ & 67,66 & $63 \%, 66 \%$ & $21 \%, 19 \%$ & $47 \%, 46 \%$ & $27 \%, 27 \%$ & $52 \%, 47 \%$ & $60 \%, 61 \%$ &,-- \\
\hline Taramasso $2012^{15}$ & 68,65 & $83 \%, 77 \%$ & $23 \%, 10 \%$ & $71 \%, 48 \%$ & $100 \%, 100 \%$ & $85 \%, 67 \%$ & $28 \%, 39 \%$ & $22 \%, 10 \%$ \\
\hline Conradi $2013^{16}$ & 72,65 & $64 \%, 45 \%$ & $46 \%, 11 \%$ & $53 \%, 29 \%$ & $86 \%, 96 \%$ & $98 \%, 88 \%$ & $36 \%, 42 \%$ & $34 \%, 10 \%$ \\
\hline Paranskaya $2013^{17}$ & 80,63 & $42 \%, 65 \%$ & $8 \%, 0 \%$ & $58 \%, 23 \%$ & $33 \%, 27 \%$ & $88 \%, 96 \%$ & $58 \%, 59 \%$ & $12 \%, 4 \%$ \\
\hline Swaans $2014^{18}$ & 75,70 & $68 \%, 51 \%$ & $42 \%, 17 \%$ & $64 \%, 53 \%$ & $77 \%, 59 \%$ & $89 \%, 89 \%$ & $37 \%, 44 \%$ & $24 \%, 14 \%$ \\
\hline Buzzatti $2014^{19}$ & 85,82 &,-- & $12 \%, 6 \%$ & $28 \%, 20 \%$ & $100 \%, 100 \%$ & $68 \%, 37 \%$ & $60 \%, 61 \%$ & $19 \%, 8 \%$ \\
\hline De Bonis $2015^{20}$ & 68,63 & $84 \%, 69 \%$ & $24 \%, 6 \%$ & $73 \%, 66 \%$ & $100 \%, 100 \%$ & $82 \%, 86 \%$ & $28 \%, 29 \%$ & $19 \%, 11 \%$ \\
\hline Ondrus $2016^{21}$ & 75,76 & $75 \%, 56 \%$ & $63 \%, 31 \%$ & $62 \%, 74 \%$ & $100 \%, 100 \%$ & $88 \%, 92 \%$ & $31 \%, 30 \%$ & $18 \%, 14 \%$ \\
\hline Alozie $2017^{22}$ & 82,82 & $57 \%, 45 \%$ & $17 \%, 17 \%$ & $88 \%, 44 \%$ & $50 \%, 41 \%$ & $89 \%, 81 \%$ & $48 \%, 53 \%$ & $11 \%, 12 \%$ \\
\hline Pooled characteristics & 72,69 & $67 \%, 61 \%$ & $30 \%, 14 \%$ & $70 \%, 46 \%$ & $66 \%, 74 \%$ & $78 \%, 74 \%$ & $44 \%, 45 \%$ & $23 \%, 11 \%$ \\
\hline$P$-value & $<0.001$ & 0.05 & $<0.001$ & $<0.001$ & 0.63 & 0.09 & 0.05 & $<0.001$ \\
\hline
\end{tabular}

versus 5\% (OR: $0.58,95 \% \mathrm{CI}: 0.28-1.19, \mathrm{p}=0.14)$ overall in eight studies; one-year mortality $12 \%$ versus $13 \%$ (OR: 1.09 , 95\% CI: $0.71-1.68, \mathrm{p}=0.69)$ in seven studies; and long-term mortality $30 \%$ versus 35\% (OR: 0.99, 95\% CI: 0.69-1.4, p=0.97) in four studies, respectively.

Pooled in-hospital complications rates are listed in Table 3. MitraClip patients had higher early significant MR, $12 \%$ vs $1 \%$ (OR 4.6, 95\% CI: 1.5-14, p=0.008) in eight studies; but lower bleeding rates $10 \%$ vs $27 \%$ (OR 0.26 , 95\% CI: $0.12-0.53$, $\mathrm{p}<0.001$ ) in five studies; and pacemaker implantation $0 \%$ vs $17 \%$ (OR 6.64, 95\% CI: 3.78-11.6, $\mathrm{p}=0.01$ ) in two studies compared to MVS patients, respectively.
Table 4 shows a pooled analysis of long-term complication rates during follow-up. MitraClip patients had higher rates of late significant MR, 22\% vs 4\% (OR 0.15, 95\% CI: 0.09-0.26, p<0.01) in six studies and cardiovascular readmission rates, $20 \%$ vs $10 \%$ (OR 2.2, 95\% CI: 1.0-5.0, $\mathrm{p}=0.05$ ) in four studies, with no differences in symptom improvement and re-operation.

\section{Discussion}

This meta-analysis compared the outcomes of the percutaneous MitraClip procedure with those of MVS for severe MR, with some important findings. In high-risk patients with primary or secondary MR, the MitraClip procedure had similar outcomes to MVS

Table 3. Pooled in-hospital morbidity outcomes.

\begin{tabular}{|l|c|c|c|c|c|c|}
\hline \multicolumn{1}{|c|}{ In-hospital outcome } & Studies & MitraClip (\%) & Mitral valve surgery (\%) & OR or WMD & 95\% Cl & $\boldsymbol{p}$-value \\
\hline Procedural failure (\%) & 8 & $4 \%$ & $2 \%$ & 1.9 & $0.71-4.8$ & 0.21 \\
\hline Neurological event (\%) & 8 & $0.8 \%$ & $3 \%$ & 0.47 & $0.17-1.3$ & 0.15 \\
\hline Myocardial infarction (\%) & 6 & $0.2 \%$ & $0.5 \%$ & 0.65 & $0.10-4.2$ & 0.66 \\
\hline Bleeding (\%) & 5 & $10 \%$ & $27 \%$ & 0.26 & $0.12-0.53$ & $<0.001$ \\
\hline Acute kidney injury (\%) & 6 & $7 \%$ & $17 \%$ & 0.50 & $0.19-1.4$ & 0.17 \\
\hline Pacemaker implantation (\%) & 2 & $0 \%$ & $17 \%$ & 0.07 & $0.01-0.57$ & 0.01 \\
\hline Length of hospital stay (days) & 7 & 10 & 11 & -2.2 & $-6.9-+2.5$ & 0.36 \\
\hline Early MR (\%) & 8 & $12 \%$ & $1 \%$ & 4.5 & $1.5-14$ & 0.008 \\
\hline Cl: confidence interval; MR: significant at least moderate mitral regurgitation; OR: odds ratio; WMD: weighted mean difference \\
\hline
\end{tabular}

Table 4. Pooled morbidity outcomes during follow-up.

\begin{tabular}{|l|c|c|c|c|c|c|}
\hline \multicolumn{1}{|c|}{ Outcome during follow-up } & Studies & MitraClip (\%) & Mitral valve surgery (\%) & OR & $95 \%$ CI & p-value \\
\hline Late significant MR (\%) & 6 & $22 \%$ & $4 \%$ & 6.6 & $3.8-12$ & $<0.001$ \\
\hline Re-operation (\%) & 3 & $6 \%$ & $3 \%$ & 2.1 & $0.8-5.4$ & 0.12 \\
\hline Cardiovascular readmission (\%) & 4 & $20 \%$ & $10 \%$ & 2.2 & $1.0-5.0$ & 0.05 \\
\hline Reduction in NYHA 3-4 (\%) & 7 & $60 \%$ & $55 \%$ & 1.4 & $0.96-2.00$ & 0.08 \\
\hline
\end{tabular}


in terms of operative mortality, mortality at one year, and beyond. MitraClip patients had lower rates of periprocedural complications of bleeding and pacemaker implantation, whereas the rates of other complications such as stroke, myocardial infarction and acute kidney injury were similar to those of MVS. The disadvantages of the MitraClip procedure were higher rates of significant residual MR, both early and later on, as well as cardiovascular readmissions during follow-up.

Only one of the nine studies was a randomised trial

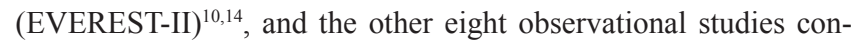
tributed to the discrepancies in baseline characteristics between MitraClip and MVS candidates ${ }^{15-22}$. That MitraClip patients had higher baseline risk, with older age, a higher proportion of previous cardiac surgery, coronary artery disease and higher EuroSCOREs seen across the studies was not surprising as the MitraClip procedure was introduced as a potential alternative for patients who are either at high or prohibitive risk for MVS ${ }^{1,2}$. There is a wealth of experience for MVS as an effective strategy in low and intermediate risk MR candidates, with low operative mortality rates around $3 \%$ overall and good durability ${ }^{1,23}$. The corollary of this is that, had we found MitraClip patients had slightly worse outcomes than MVS, then it would be difficult to discern whether this was due to higher baseline risk or that the MitraClip procedure was truly inferior to MVS.

Despite the aforementioned differences at baseline, there were no differences in mortality outcomes between the two modalities. The pooled operative mortality rate of $3-5 \%$ is acceptable in this selectively higher risk cohort, and similar to that of allcomers undergoing either procedure for severe $\mathrm{MR}^{23}$. Operative mortality is an important safety measurement and long-term survival illustrates efficacy for valvular procedures. These results are especially reassuring for the MitraClip cohort, which had similar mortality rates to MVS, despite having higher baseline risk than MVS, and they highlight the utility of MitraClip in high-risk candidates warranting intervention, including those with ischaemic and functional MR and/or cardiomyopathy. Of note, the original EuroSCORE, which estimated operative mortality after cardiac surgery reported in these studies, grossly over-estimated that of MitraClip, estimated as $23 \%$ vs $3 \%$ actual, and to a lesser extent MVS, estimated as $11 \%$ versus $5 \%$ actual ${ }^{24}$. Although the more contemporary EuroSCORE II and STS scores were not routinely reported, they fit better with contemporary outcomes ${ }^{25-27}$. They can assist patient selection for the MitraClip procedure after determining which patients are at high risk for MVS. Unlike for MVS however, caution needs to be taken when applying these scores directly to the MitraClip procedure due to over-estimation and modest discriminative ability ${ }^{28}$.

Although procedural failure rates were relatively low, the main shortcomings of the MitraClip procedure are the high rates of residual MR, and possibly short- and long-term durability, being significantly worse than MVS. This finding was consistent across all studies ${ }^{10,13-21}$. Residual MR, especially moderate or severe, is to be avoided as it is associated with worse clinical outcomes ${ }^{19,30}$. Although this did not translate to statistically higher rates of reoperation during follow-up, this could have been because many of these high-risk at baseline candidates would have been ineligible or at too high a risk for reintervention. Whereas there are many MVS techniques to restrict residual MR, the MitraClip procedure, which mimics the Alfieri edge to edge surgical technique by clipping the two mitral valve leaflets together creating two small MV orifices, does not have the same capability ${ }^{9}$. Notably, most of the eligible studies in our meta-analysis used the earlier-generation MitraClip device and about half started enrolling patients before 2008, when the technique was in its infancy. With increasing experience over time, the reported early residual MR rate reduced to approximately $5 \%$ in the COAPT trial and contemporary registries ${ }^{13,31}$. Furthermore, a number of other percutaneous mitral valve intervention techniques are being developed and are in active clinical trials to try and overcome these shortcomings. These techniques include mitral annuloplasty, chordal replacement, mid-leaflet attachment to each side of small spacer (PASCAL system), ventricle remodelling and valve replacement ${ }^{32-35}$. Their reported rates of significant early MR are similarly at $<5 \%$.

Other periprocedural complications noted in the meta-analysis were either similar in occurrence (stroke, myocardial infarction and acute kidney injury) or higher for MVS (bleeding and pacemaker implantation). These findings are similar to other comparisons between transcatheter and surgical approaches to cardiovascular diseases, such as transcatheter versus surgical aortic valve replacement for aortic stenosis ${ }^{36,37}$. However, unlike transcatheter aortic valve implantation, the MitraClip procedure has a low risk of requiring pacemaker implantation as the MitraClip is deployed far from the heart's native conduction system, whereas both mitral and aortic valve surgeries have significant risk of pacemaker implantation, typically at least $5 \%{ }^{38}$. The proximity of the bioprosthetic aortic valve implanted by the transcatheter approach to the atrio-ventricular node increases the risk of heart block, requiring pacemakers at a rate comparable to those required following valve surgery ${ }^{36,37}$, whereas the landing zone for MitraClip is distant to the conduction system hence a low risk of pacemaker implantation $(0 \%$ in our meta-analysis). Of some concern for the MitraClip procedure, however, is the higher rate of cardiovascular readmissions during followup compared to those for MVS in the pooled analysis, despite similar NYHA status. This is another important efficacy measure especially with many of these patients having heart failure admissions, likely in part due to greater residual MR and probably higher filling pressures for MitraClip. The hope is that with further experience and advances in percutaneous mitral valve techniques, cardiovascular readmissions may be reduced to similar rates as for MVS.

Secondary MR deserves a special mention, as the optimal interventional strategy remains controversial ${ }^{1,2}$. In our meta-analysis secondary MR was common at baseline in both arms, being present in $66-74 \%$ of patients, though there was a higher proportion 
of coronary artery disease in MitraClip vs MVS patients, with no differences in mortality endpoints. It is important to note that prior studies, including randomised trials, have not demonstrated a significant benefit for survival by performing MVS in addition to coronary artery surgery in the setting of secondary or ischaemic $\mathrm{MR}^{1,2,8,9}$. Two recent randomised trials specifically compared the MitraClip procedure with medical therapy for secondary MR with heart failure, with conflicting results ${ }^{12,13}$. The MITRA-FR trial found no difference between the MitraClip procedure or medical therapy alone in terms of death and heart failure hospitalisation ${ }^{12}$, whereas COAPT found significant reduction in both endpoints in favour of the MitraClip procedure ${ }^{13}$. The COAPT trial was larger, with longer follow-up, had higher heart failure biomarker levels and more severe MR that was disproportionate to the underlying cardiomyopathy's remodelling of the left ventricle, as compared with the MITRA-FR trial, which may explain, in part, the discrepancy in their findings ${ }^{39}$. These sicker patients with secondary MR, both functional and ischaemic, are likely those to be targeted to benefit from MitraClip intervention.

\section{Limitations}

This meta-analysis has some limitations. The majority of studies were observational with inherent biases in patient selection and different baseline risk profiles which, as described earlier, influence the interpretation of the findings. There was also heterogeneity in study design including patient inclusion, aetiology of MR, intervention strategy, and type and timing of characteristics endpoints. Despite pooling nine studies, the overall sample size is moderate, at best, for determining differences in endpoints, especially ones which occur rarely or are infrequently reported. Comparison with a non-interventional medical approach was not assessed. Some important endpoints such as quality of life were not reported. Follow-up was also limited to, at most, five years. Longer-term durability and outcomes of the MitraClip procedure compared to MVS remain important unknowns, especially if the MitraClip procedure is being introduced to treat lower-risk and/or younger candidates in the future. Finally, the eligible studies took place between 2011-2017 and may not fully capture the contemporary experience, because the focus of more recent studies of the MitraClip procedure are either single-armed registries or comparisons with medical therapy for secondary MR or other percutaneous techniques, rather than MVS.

\section{Conclusions}

Patients with severe MR had similar mortality early and late after the MitraClip procedure compared to MVS, despite a higher baseline risk for MitraClip candidates. The main disadvantage of the MitraClip procedure is residual post-procedural MR in the shortand long-term and cardiovascular readmissions, whereas MVS had more periprocedural complications of bleeding and pacemaker implantation. A multidisciplinary and individualised approach with sound clinical judgement is required for deciding the optimal treatment modality for high-risk severe MR patients.

\section{Impact on daily practice}

This meta-analysis of 9 studies and 1,171 patients showed that although percutaneous MitraClip patients have a higher baseline risk than MVS patients, mortality early, at one year and at three years were similar. MitraClip patients had higher rates of residual post-procedural MR and cardiovascular readmissions, but a lower risk of periprocedural complications, especially bleeding and pacemaker implantation, compared to MVS. MitraClip should be considered as an alternative to MVS particularly for high-risk candidates.

\section{Conflict of interest statement}

The authors have no conflicts of interest to declare.

\section{References}

1. Baumgartner H, Falk V, Bax JJ, De Bonis M, Hamm C, Holm PJ, Iung B, Lancellotti P, Lansac E, Rodriguez Muñoz D, Rosenhek R, Sjögren J, Tornos Mas P, Vahanian A, Walther T, Wendler O, Windecker S, Zamorano JL; ESC Scientific Document Group. 2017 ESC/EACTS Guidelines for the management of valvular heart disease. Eur Heart J. 2017;38:2739-91.

2. Nishimura RA, Otto CM, Bonow RO, Carabello BA, Erwin JP 3rd, Guyton RA, O'Gara PT, Ruiz CE, Skubas NJ, Sorajja P, Sundt TM 3rd, Thomas JD. 2014 AHA/ACC guideline for the management of patients with valvular heart disease: a report of the American College of Cardiology/American Heart Association Task Force on Practice Guidelines. J Am Coll Cardiol. 2014;63: e57-185

3. Jones EC, Devereux RB, Roman MJ, Liu JE, Fishman D, Lee ET, Welty TK, Fabsitz RR, Howard BV. Prevalence and correlates of mitral regurgitation in a population-based sample (the Strong Heart Study). Am J Cardiol. 2001;87:298-304.

4. Iung B, Baron G, Butchart EG, Delahaye F, Gohlke-Barwolf C, Levang OW, Tornos P, Vanoverschelde JL, Vermeer F, Boersma E, Ravaud P, Vahanian A. A prospective survey of patients with valvular heart disease in Europe: the Euro Heart Survey on Valvular Heart Disease. Eur Heart J. 2003;24:1231-43.

5. Nkomo VT, Gardin JM, Skelton TN, Gottdiener JS, Scott CG, Enriquez-Sarano M. Burden of valvular heart diseases: a population-based study. Lancet. 2006;368:1005-11.

6. Grigioni F, Enriquez-Sarano M, Zehr KJ, Bailey KR, Tajik AJ. Ischemic mitral regurgitation: long-term outcome and prognostic implications with quantitative Doppler assessment. Circulation. 2001;103:1759-64.

7. De Bonis M, Al-Attar N, Antunes M, Borger M, Casselman F, Falk V, Folliguet T, Iung B, Lancellotti P, Lentini S, Maisano F, Messika-Zeitoun D, Muneretto C, Pibarot P, Pierard L, Punjabi P, Rosenhek R, Suwalski P, Vahanian A, Wendler O, Prendergast B. Surgical and interventional management of mitral valve regurgitation: a position statement from the European Society of Cardiology Working Groups on Cardiovascular Surgery and Valvular Heart Disease. Eur Heart J. 2016;37:133-9. 
8. Acker MA, Parides MK, Perrault LP, Moskowitz AJ, Gelijns AC, Voisine P, Smith PK, Hung JW, Blackstone EH, Puskas JD, Argenziano M, Gammie JS, Mack M, Ascheim DD, Bagiella E, Moquete EG, Ferguson TB, Horvath KA, Geller NL, Miller MA, Woo YJ, D'Alessandro DA, Ailawadi G, Dagenais F, Gardner TJ, O'Gara PT, Michler RE, Kron IL; CTSN. Mitral valve repair versus replacement for severe ischaemic regurgitation. $N$ Engl J Med. 2014:370:23-32.

9. Smith PK, Puskas JD, Ascheim DD, Voisine P, Gelijns AC, Moskowitz AJ, Hung JW, Parides MK, Ailawadi G, Perrault LP, Acker MA, Argenziano M, Thourani V, Gammie JS, Miller MA, Pagé P, Overbey JR, Bagiella E, Dagenais F, Blackstone EH, Kron IL, Goldstein DJ, Rose EA, Moquete EG, Jeffries N, Gardner TJ, O'Gara PT, Alexander JH, Michler RE; Cardiothoracic Surgical Trials Network Investigators. Surgical treatment of moderate ischemic mitral regurgitation. $N$ Engl J Med. 2014;371: 2178-88

10. Maisano F, La Canna G, Colombo A, Alfieri O. The evolution from surgery to percutaneous mitral valve interventions: the role of the edge-to-edge technique. J Am Coll Cardiol. 2011;58: 2174-82.

11. Feldman T, Foster E, Glower DD, Kar S, Rinaldi MJ, Fail PS, Smalling RW, Siegel R, Rose GA, Engeron E, Loghin C, Trento A, Skipper ER, Fudge T, Letsou GV, Massaro JM, Mauri L; EVEREST II Investigators. Percutaneous repair or surgery for mitral regurgitation. N Engl J Med. 2011;364:1395-406.

12. Obadia JF, Messika-Zeitoun D, Leurent G, Iung B, Bonnet G, Piriou N, Lefèvre T, Piot C, Rouleau F, Carrié D, Nejjari M, Ohlmann P, Leclercq F, Saint Etienne C, Teiger E, Leroux L, Karam N, Michel N, Gilard M, Donal E, Trochu JN, Cormier B, Armoiry X, Boutitie F, Maucort-Boulch D, Barnel C, Samson G, Guerin P, Vahanian A, Mewton N; MITRA-FR Investigators. Percutaneous Repair or Medical Treatment for Secondary Mitral Regurgitation. N Engl J Med. 2018;379:2297-306.

13. Stone GW, Lindenfeld J, Abraham WT, Kar S, Lim DS, Mishell JM, Whisenant B, Grayburn PA, Rinaldi M, Kapadia SR, Rajagopal V, Sarembock IJ, Brieke A, Marx SO, Cohen DJ, Weissman NJ, Mack MJ; COAPT Investigators. Transcatheter Mitral-Valve Repair in Patients with Heart Failure. N Engl J Med. 2018;379:2307-18.

14. Feldman T, Kar S, Elmariah S, Smart SC, Trento A, Siegel RJ, Apruzzese P, Fail P, Rinaldi MJ, Smalling RW, Hermiller JB, Heimansohn D, Gray WA, Grayburn PA, Mack MJ, Lim DS, Ailawadi G, Herrmann HC, Acker MA, Silvestry FE, Foster E, Wang A, Glower DD, Mauri L; EVEREST II Investigators. Randomized Comparison of Percutaneous Repair and Surgery for Mitral Regurgitation: 5-Year Results of EVEREST II. J Am Coll Cardiol. 2015;66:2844-54.

15. Taramasso M, Denti P, Buzzatti N, De Bonis M, La Canna G, Colombo A, Alfieri O, Maisano F. Mitraclip therapy and surgical mitral repair in patients with moderate to severe left ventricular failure causing functional mitral regurgitation: a single-centre experience. Eur J Cardiothorac Surg. 2012;42:920-6.
16. Conradi L, Treede H, Rudolph V, Graumüller P, Lubos E, Baldus S, Blankenberg S, Reichenspurner H. Surgical or percutaneous mitral valve repair for secondary mitral regurgitation: comparison of patient characteristics and clinical outcomes. Eur $J$ Cardiothorac Surg. 2013;44:490-6.

17. Paranskaya L, D’Ancona G, Bozdag-Turan I, Akin I, Kische S, Turan GR, Rehders T, Schneider H, Westphal B, Birkemeyer R, Nienaber CA, Ince H. Percutaneous vs surgical repair of mitral valve regurgitation: single institution early and midterm outcomes. Can J Cardiol. 2013;29:452-9.

18. Swaans MJ, Bakker AL, Alipour A, Post MC, Kelder JC, de Kroon TL, Eefting FD, Rensing BJ, Van der Heyden JA. Survival of transcatheter mitral valve repair compared with surgical and conservative treatment in high-surgical-risk patients. JACC Cardiovasc Interv. 2014;7:875-81.

19. Buzzatti N, Maisano F, Latib A, Taramasso M, Denti P, La Canna G, Colombo A, Alfieri O. Comparison of outcomes of percutaneous MitraClip versus surgical repair or replacement for degenerative mitral regurgitation in octogenarians. Am $J$ Cardiol. 2015;115:487-92.

20. De Bonis M, Taramasso M, Lapenna E, Denti P, La Canna G, Buzzatti N, Pappalardo F, Di Giannuario G, Cioni M, Giacomini A, Alfieri O. MitraClip therapy and surgical edge-to-edge repair in patients with severe left ventricular dysfunction and secondary mitral regurgitation: mid-term results of a single-centre experience†. Eur J Cardiothorac Surg. 2016;49:255-62.

21. Ondrus T, Bartunek J, Vanderheyden M, Stockman B, Kotrc M, Van Praet F, Van Camp G, Lecomte P, Mo Y, Penicka M. Minimally invasive mitral valve repair for functional mitral regurgitation in severe heart failure: MitraClip versus minimally invasive surgical approach. Interact Cardiovasc Thorac Surg. 2016;23:784-9.

22. Alozie A, Paranskaya L, Westphal B, Kaminski A, Sherif M, Sindt M, Kische S, Schubert J, Diedrich D, Ince H, Steinhoff G, Öner A. Clinical outcomes of conventional surgery versus MitraClip ${ }^{\circledR}$ therapy for moderate to severe symptomatic mitral valve regurgitation in the elderly population: an institutional experience. BMC Cardiovasc Disord. 2017;17:85.

23. Badhwar V, Rankin JS, He X, Jacobs JP, Gammie JS, Furnary AP, Fazzalari FL, Han J, O'Brien SM, Shahian DM. The Society of Thoracic Surgeons Mitral Repair/Replacement Composite Score: A Report of The Society of Thoracic Surgeons Quality Measurement Task Force. Ann Thorac Surg. 2016;101:2265-71.

24. Roques F, Michel P, Goldstone AR, Nashef SA. The logistic EuroSCORE. Eur Heart J. 2003;24:881-2.

25. Nashef SA, Roques F, Sharples LD, Nilsson J, Smith C, Goldstone AR, Lockowandt U. EuroSCORE II. Eur J Cardiothorac Surg. 2012;41:734-44.

26. O'Brien SM, Shahian DM, Filardo G, Ferraris VA, Haan CK, Rich JB, Normand SL, DeLong ER, Shewan CM, Dokholyan RS, Peterson ED, Edwards FH, Anderson RP; Society of Thoracic Surgeons Quality Measurement Task Force. The Society of Thoracic Surgeons 2008 cardiac surgery risk models: part 2--isolated valve surgery. Ann Thorac Surg. 2009;88:S23-42. 
27. Wang TK, Harmos S, Gamble GD, Ramanathan T, Ruygrok PN. Performance of contemporary surgical risk scores for mitral valve surgery. J Card Surg. 2017;32:172-6.

28. Adamo M, Capodanno D, Cannata S, Giannini C, Laudisa ML, Barbanti M, Curello S, Immè S, Maffeo D, Grasso C, Bedogni F, Petronio AS, Ettori F, Tamburino C; GRASP-IT Investigators. Comparison of three contemporary surgical scores for predicting all-cause mortality of patients undergoing percutaneous mitral valve repair with the MitraClip system (from the multicenter GRASP-IT registry). Am J Cardiol. 2015;115:107-12.

29. Kaneko H, Neuss M, Weissenborn J, Butter C.Impact of residual mitral regurgitation after MitraClip implantation. Int J Cardiol. 2017;227:813-9.

30. Buzzatti N, De Bonis M, Denti P, Barili F, Schiavi D, Di Giannuario G, La Canna G, Alfieri O. What is a "good" result after transcatheter mitral repair? Impact of 2+ residual mitral regurgitation. J Thorac Cardiovasc Surg. 2016;151:88-96

31. Chhatriwalla AK, Vemulapalli S, Holmes DR Jr, Dai D, Li Z, Ailawadi G, Glower D, Kar S, Mack MJ, Rymer J, Kosinski AS, Sorajja P. Institutional Experience With Transcatheter Mitral Valve Repair and Clinical Outcomes: Insights From the TVT Registry. JACC Cardiovasc Interv. 2019;12:1342-52.

32. Siminiak T, Wu JC, Haude M, Hoppe UC, Sadowski J, Lipiecki J, Fajadet J, Shah AM, Feldman T, Kaye DM, Goldberg SL, Levy WC, Solomon SD, Reuter DG. Treatment of functional mitral regurgitation by percutaneous annuloplasty: results of the TITAN Trial. Eur J Heart Fail. 2012;14:931-8.

33. Praz F, Spargias K, Chrissoheris M, Büllesfeld L, Nickenig G, Deuschl F, Schueler R, Fam NP, Moss R, Makar M, Boone R, Edwards J, Moschovitis A, Kar S, Webb J, Schäfer U, Feldman T, Windecker S. Compassionate use of the PASCAL transcatheter mitral valve repair system for patients with severe mitral regurgitation: a multicentre, prospective, observational, first-in-man study. Lancet. 2017;390:773-80.
34. Muller DWM, Farivar RS, Jansz P, Bae R, Walters D, Clarke A, Grayburn PA, Stoler RC, Dahle G, Rein KA, Shaw M, Scalia GM, Guerrero M, Pearson P, Kapadia S, Gillinov M, Pichard A, Corso P, Popma J, Chuang M, Blanke P, Leipsic J, Sorajja P; Tendyne Global Feasibility Trial Investigators. Transcatheter Mitral Valve Replacement for Patients With Symptomatic Mitral Regurgitation: A Global Feasibility Trial. J Am Coll Cardiol. 2017;69:381-91.

35. Takagi H, Hari Y, Kawai N, Kuno T, Ando T; ALICE (AllLiterature Investigation of Cardiovascular Evidence) Group. Transcatheter mitral valve replacement for mitral regurgitation A meta-analysis. J Card Surg. 2018;33:827-35.

36. Smith CR, Leon MB, Mack MJ, Miller DC, Moses JW, Svensson LG, Tuzcu EM, Webb JG, Fontana GP, Makkar RR, Williams M, Dewey T, Kapadia S, Babaliaros V, Thourani VH, Corso P, Pichard AD, Bavaria JE, Herrmann HC, Akin JJ, Anderson WN, Wang D, Pocock SJ; PARTNER Trial Investigators. Transcatheter versus surgical aortic-valve replacement in high-risk patients. N Engl J Med. 2011;364:2187-98.

37. Leon MB, Smith CR, Mack MJ, Makkar RR, Svensson LG, Kodali SK, Thourani VH, Tuzcu EM, Miller DC, Herrmann HC, Doshi D, Cohen DJ, Pichard AD, Kapadia S, Dewey T, Babaliaros V, Szeto WY, Williams MR, Kereiakes D, Zajarias A, Greason KL, Whisenant BK, Hodson RW, Moses JW, Trento A, Brown DL, Fearon WF, Pibarot P, Hahn RT, Jaber WA, Anderson WN, Alu MC, Webb JG; PARTNER 2 Investigators. Transcatheter or Surgical Aortic-Valve Replacement in Intermediate-Risk Patients. $N$ Engl J Med. 2016;374:1609-20.

38. Leyva F, Qiu T, McNulty D, Evison F, Marshall H, Gasparini M. Long-term requirement for pacemaker implantation after cardiac valve replacement surgery. Heart Rhythm. 2017;14:529-34.

39. Grayburn PA, Sannino A, Packer M. Proportionate and Disproportionate Functional Mitral Regurgitation: A New Conceptual Framework That Reconciles the Results of the MITRA-FR and COAPT Trials. JACC Cardiovasc Imaging. 2019;12:353-62. 